\title{
Tracers to investigate protein and amino acid metabolism in human subjects
}

\author{
Anton J. M. Wagenmakers \\ Department of Human Biology, NUTRIM, Maastricht University, PO Box 616, 6200 MD Maastricht, \\ The Netherlands
}

Three tracer methods have been used to measure protein synthesis, protein breakdown and protein oxidation at whole-body level. The method using L- $\left[1-{ }^{13} \mathrm{C}\right]$ leucine is considered the method of reference. These methods have contributed greatly to the existing knowledge on whole-body protein turnover and its regulation by feeding, fasting, hormones and disease. How exercise and ingestion of mixed protein-containing meals affect whole-body protein metabolism is still open to debate, as there are discrepancies in results obtained with different tracers. The contribution of whole-body methods to the future gain of knowledge is expected to be limited due to the fact that most physiological disturbances have been investigated extensively, and due to the lack of information on the relative contribution of various tissues and proteins to whole-body changes. Tracer amino acid-incorporation methods are most suited to investigate these latter aspects of protein metabolism. These methods have shown that some tissues (liver and gut) have much higher turnover rates and deposit much more protein than others (muscle). Massive differences also exist between the fractional synthesis rates of individual proteins. The incorporation methods have been properly validated, although minor disagreements remain on the identity of the true precursor pool (the enrichment of which should be used in the calculations). Arterio-venous organ balance studies have shown that little protein is deposited in skeletal muscle following a proteincontaining meal, while much more protein is deposited in liver and gut. The amount deposited in the feeding period in each of these tissues is released again during overnight fasting. The addition of tracers to organ balance studies allows the simultaneous estimation of protein synthesis and protein breakdown, and provides information on whether changes in net protein balance are caused primarily by a change in protein synthesis or in protein breakdown. In the case of a small arterio-venous difference in a tissue with a high blood flow, estimates of protein synthesis and breakdown become very uncertain, limiting the value of using the tracer. An additional measurement of the intracellular free amino acid pool enrichment allows a correction for amino acid recycling and quantification of the inward and outward transmembrane transport. However, in order to obtain reliable estimates of the intramuscular amino acid enrichment and, therefore, of muscle protein synthesis and breakdown in this so-called three-pool model, the muscle should be freeze-dried and the resulting fibres should be freed from connective tissue and small blood clots under a dissection microscope. Even when optimal precautions are taken, the calculations in these tracer balance methods use multiple variables and, therefore, are bound to lead to more variability in estimates of protein synthesis than the tracer amino acid incorporation methods. In the future, most studies should focus on the measurement of protein synthesis and breakdown in specific proteins in order to understand the mechanisms behind tissue adaptation in response to various stimuli (feeding, fasting, exercise, trauma, sepsis, disuse and disease). The tracer laboratories, therefore, should improve the methodology to allow the measurement of low tracer amino acid enrichments in small amounts of protein.

Protein turnover: Skeletal muscle: Exercise: Arterio-venous difference: Tracer balance methods

\footnotetext{
Abbreviations: FSR, fractional synthesis rate; IRMS, isotope-ratio mass spectrometry; $\alpha$-KIC, $\alpha$-ketoisocaproic acid; MS, mass spectrometry; nb, net balance of tracer; NB, net balance of tracee; Ra, rate of appearance; Rd, rate of disappearance.

Corresponding author: Dr Anton Wagenmakers, fax +31 43 3670976, email A.Wagenmakers@HB.Unimaas.NL
} 
The body of a $70 \mathrm{~kg}$ man contains in total $12 \mathrm{~kg}$ protein (amino acid polymers) and $220 \mathrm{~g}$ free amino acids. There are thousands of different proteins, distributed among all cells and body fluids, each with its own specific amino acid sequence, three-dimensional structure and function (e.g. enzymes, transport proteins, hormones, DNA- and RNAprocessing proteins, structural proteins, contractile proteins etc.). In order to maintain the structural and functional integrity there is a continuous turnover of protein (synthesis and breakdown occur simultaneously). In a healthy adult human subject ingesting adequate amounts of dietary protein, protein synthesis equals protein breakdown on a $24 \mathrm{~h}$ basis, implying that whole-body protein mass is in balance.

However, in many conditions such as after overnight fasting, long-term starvation, neuromuscular and acquired disabling diseases, ageing, cancer and pulmonary obstructions, there is a gradual progressive loss of protein. In all these cases the tissue most affected is skeletal muscle. Patients with major trauma and sepsis may lose up to $50 \%$ of the muscle protein over 2 weeks, and as a consequence become so weak that mechanical ventilation becomes essential for survival. Skeletal muscle accounts for $400-450 \mathrm{~g} / \mathrm{kg}$ total body mass and contains about $7 \mathrm{~kg}$ protein, primarily in the form of contractile proteins (myofibrillar proteins, primarily actin and myosin). Muscle also contains over $60 \%$ of the free amino acids in our body. During starvation, gluconeogenic amino acids (mainly glutamine and alanine) are released from muscle as precursors for glucose production in liver and kidneys to serve as fuel for the brain. Muscle wasting in cancer, severe trauma and sepsis serves to generate amino acid precursors for wound healing, tissue repair and synthesis of antibodies and acute-phase proteins, in addition to gluconeogenesis. Muscle wasting in most of these catabolic diseases eventually leads to muscle weakness and major disabilities in day-to-day life. This situation has led to many attempts to reduce or reverse the losses of muscle protein and function by various interventions. Different genes are expressed in different tissues, which leads to differences in the protein and enzyme package of each organ and tissue during embryonic growth and development. Differences in genetic information lead to differences in the protein composition of the bodies of individuals, and in the activities of key enzymes in substrate metabolism in their cells and body fluids, and therefore indirectly play a role in the possibility of developing obesity, type 2 diabetes and cardiovascular disease. Changes in nutrition and habitual physical activity have an impact on gene expression in certain tissues, and may lead to shifts in the protein content of the cells (adaptation). Again, skeletal muscle is an interesting and potentially central tissue here. Strength training is known to lead to increased expression and deposition of the myofibrillar proteins (therefore the well-known hypertrophy and increases in strength) and does help to prevent muscle wasting during ageing. Endurance training leads to the parallel expression of a whole range of enzymes with a role in substrate transport and oxidation; disuse has the opposite effect. Individuals with low habitual activities not only have deconditioned muscles with a low oxidative capacity, but also have an increased risk for the development of obesity, cardiovascular disease and type 2 diabetes, implying that protein adaptation at the muscle level has major health consequences at whole-body level.

Our knowledge of the regulation of protein metabolism at the whole-body, muscle and organ levels in various physiological conditions is based on direct and indirect measurements of protein synthesis and breakdown, and exchange rates of amino acids and amino acid tracers between tissues. At the level of individual proteins we have an incomplete knowledge, implying that we are only beginning to understand the mechanisms behind embryonic growth and development, behind genetic differences between individuals, and behind the molecular adaptation to nutrition and exercise in a given individual. The present paper will describe how the use of tracer amino acids has contributed to the present knowledge on the regulation of protein and amino acid metabolism in human subjects, where the limitations and uncertainties of the existing methods lie, and finally which methodological developments will be necessary and which complimentary research methodologies should be used in parallel to gain new knowledge in future research on protein metabolism in vivo in human subjects. For reviews describing the current physiological knowledge of the regulation of protein and amino acid metabolism by hormones, nutrition, disease and exercise (see Waterlow et al. 1978a; Waterlow, 1984; Rennie, 1985; Hasselgren, 1995; Wagenmakers \& Soeters, 1995; Rooyackers \& Nair, 1997; Wagenmakers, 1998a,b).

\section{Whole-body protein turnover}

The first attempts to measure the rate of whole-body protein turnover in human subjects were made soon after the first radioactive isotopically-labelled amino acids became available (for references, see Garlick \& Fern, 1985). To avoid potential radiation damage, the use of radioactive tracers became restricted in human subjects and was largely replaced by the use of stable-isotope tracer amino acids. The stable-isotope tracers most often used in whole-body studies are $\left[{ }^{15} \mathrm{~N}\right]$ glycine (Waterlow et al. 1978a,b; Fern et al. 1985; Garlick \& Fern, 1985), L-[1-13 C]leucine (Matthews et al. 1980, 1982) and $\mathrm{L}-\left[{ }^{2} \mathrm{H}_{5}\right]$ phenylalanine (Thompson et al. 1989).

$\left[{ }^{15} \mathrm{~N}\right]$ glycine was the first stable-isotope tracer used for the quantification of whole-body protein turnover in vivo. In early studies (Waterlow et al. 1978a) the tracer was given as a continuous intragastric infusion (infusion rate $i$ ) until after 2-3 $\mathrm{d}$ a plateau had been reached in the labelling of urea in the urine. The enrichment in the urea pool was assumed to reflect the ${ }^{15} \mathrm{~N}$ enrichment in a single ' $\mathrm{N}$ metabolic pool' in which all free amino acids and urea eventually reached the same enrichment and from which exchange occurs with whole-body protein (Fig. 1). The whole-body $\mathrm{N}$ turnover (Q) can be calculated from the formula $\mathrm{Q}=i / \mathrm{E}_{\text {urea }}$, where $\mathrm{E}_{\text {urea }}$ is the ${ }^{15} \mathrm{~N}$ enrichment of urea. Assuming that the $\mathrm{N}$ metabolic pool is in steady-state, then the flux (i.e. Q) equals the amount of $\mathrm{N}$ leaving the pool $(\mathrm{S}+\mathrm{E}$, where $\mathrm{S}$ is synthesis and $\mathrm{E}$ is urinary $\mathrm{N}$ excretion) and equals the amount of $\mathrm{N}$ entering the pool $(\mathrm{B}+\mathrm{I}$, where $\mathrm{B}$ is breakdown and $\mathrm{I}$ is dietary intake); $\mathrm{E}$ and I can be measured and therefore $\mathrm{S}$ and $\mathrm{B}$ can be calculated. In a modification of the 


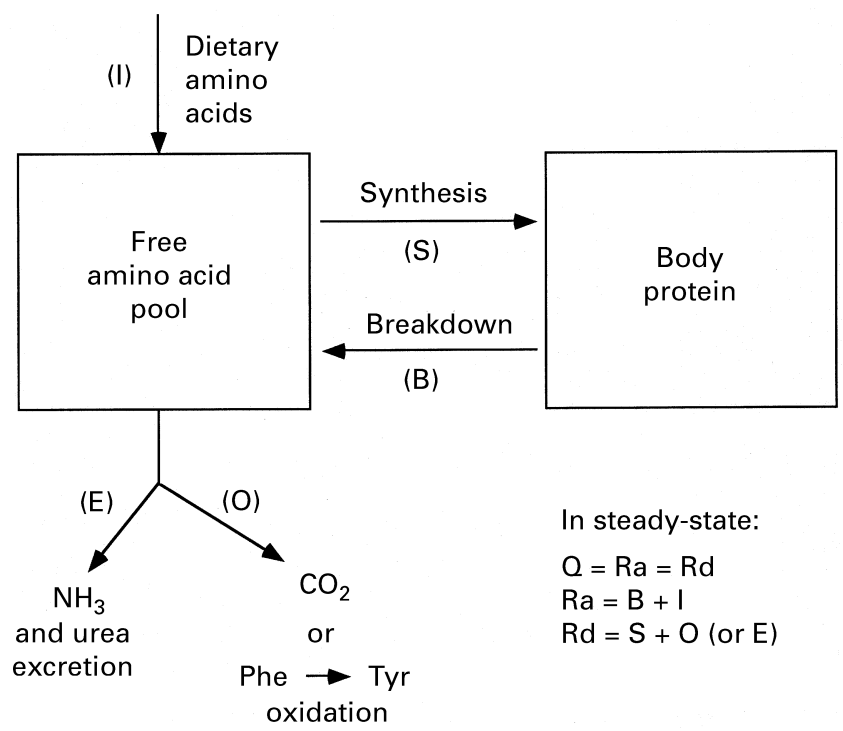

Fig. 1. General model of protein metabolism used in the whole-body methods. Q, whole-body nitrogen turnover; $\mathrm{Ra}$, rate of appearance in the free amino acid pool; Rd, rate of disappearance from the free amino acid pool; Phe, phenylalanine; Tyr, tyrosine.

$\left[{ }^{15} \mathrm{~N}\right]$ glycine method the tracer is given as a single oral dose of $200 \mathrm{mg}$ in the post-absorptive state and urine is collected for 9-12 h (Fern et al. 1981, 1985; Garlick \& Fern, 1985). This method was quite popular in the 1980s, as it is noninvasive and can be applied easily outside a laboratory. However, there are many practical difficulties (urine collections outside laboratory) and unproven assumptions which are unlikely to be valid in all physiological and pathophysiological conditions. The most critical assumption is that all amino acids mix in one $\mathrm{N}$ compartment and end up having the same enrichment. It has been shown repeatedly that there are in fact several $\mathrm{N}$ compartments, leading to differences in the ${ }^{15} \mathrm{~N}$ enrichment of urea and $\mathrm{NH}_{3}$ (in some studies, therefore, the harmonic mean is used; Fern et al. 1981, 1985). Differences also occur in the ${ }^{15} \mathrm{~N}$ enrichment of different amino acids in the free pool on equilibration, and the measured protein turnover rates differ widely for different ${ }^{15} \mathrm{~N}$-labelled amino acids (Fern et al. 1981, 1985; Garlick \& Fern, 1985). For these reasons the $\left[{ }^{15} \mathrm{~N}\right]$ glycine method is under severe criticism, and currently is not often used.

The $\mathrm{L}-\left[1-{ }^{13} \mathrm{C}\right]$ leucine tracer is given as a primed continuous intravenous infusion until after about $2 \mathrm{~h}$ a plateau has been reached in arterial leucine enrichment (Matthews et al. 1980) or venous $\alpha$-ketoisocaproic acid $(\alpha-$ KIC) enrichment. The latter (transamination product of leucine) has been suggested to better reflect the enrichment of leucine in the free amino acid pool from which direct incorporation of the leucine into whole-body protein occurs (Fig. 1; Matthews et al. 1982). The rate of appearance (Ra) in this free amino acid pool can be calculated from the tracer dilution observed at steady-state according to the formula $\mathrm{Q}=i\left(\mathrm{E}_{i} / \mathrm{E}_{\mathrm{p}}-1\right)$, where $\mathrm{Q}$ is the turnover, $i$ is the infusion rate of the tracer, $\mathrm{E}_{i}$ is the enrichment of the infused tracer and $E_{p}$ is the enrichment of the plasma precursor pool. At steady-state leucine turnover (i.e. Q) equals both the $\mathrm{Ra}$ $(\mathrm{Ra}=\mathrm{S}+\mathrm{O}$, where $\mathrm{S}$ is synthesis and $\mathrm{O}$ is oxidation) and the rate of disappearance $(\mathrm{Rd} ; \mathrm{Rd}=\mathrm{B}+\mathrm{I}$, where $\mathrm{B}$ is breakdown and $\mathrm{I}$ is the dietary intake; Fig. 1). Leucine turnover is converted to whole-body protein turnover using the average leucine content of body protein of $8 \mathrm{~g} / 100 \mathrm{~g}$ protein (Matthews et al. 1980). The oxidation of $\mathrm{L}-\left[1-{ }^{13} \mathrm{C}\right]$ leucine is quantified by measuring breath ${ }^{13} \mathrm{CO}_{2}$ enrichment (a plateau value is reached again after about $2 \mathrm{~h}$, at least when the bicarbonate pool is primed) and multiplying this enrichment by total $\mathrm{CO}_{2}$ production and a bicarbonate correction factor for losses of $\mathrm{CO}_{2}$ between the site of oxidation and appearance in the breath (van Hall, 1999). Protein synthesis (or non-oxidative $\mathrm{Ra}$ ) can then be calculated. Most tracer studies are done in the overnight-fasted state when the dietary protein intake (i.e. I in the equation $\mathrm{Rd}=\mathrm{B}+\mathrm{I}$ ) is zero. In the latter case the turnover (i.e. $Q$ in the earlier equation) equals protein breakdown (i.e. B). In the fed state protein intake should be known and should be constant with time. This situation is achieved in practice by continuous intragastric feeding or repeated oral doses, approaches which have the inevitable limitation that they clearly do not reflect normal human nutrition patterns, but neverthless this approach has been useful to investigate differences between feeding and fasting. Overall, the $\mathrm{L}-\left[1-{ }^{13} \mathrm{C}\right]$ leucine method has survived two decades of intense scrutiny and is now considered the reference method to obtain fair estimates of whole-body protein metabolism in most physiological conditions.

The $\mathrm{L}-\left[{ }^{2} \mathrm{H}_{5}\right]$ phenylalanine tracer is given as a primed continuous intravenous infusion with an additional $\mathrm{L}-\left[{ }^{2} \mathrm{H}_{4}\right]$ tyrosine primer. After about $2 \mathrm{~h}$ a plateau is reached in the plasma enrichment of both these tracers, and flux can be calculated from the arterial plasma phenylalanine dilution. The first step in the oxidation of phenylalanine is hydroxylation in the liver to tyrosine. The rate of oxidation, therefore, can be quantified from the enrichment of $\mathrm{L}-\left[{ }^{2} \mathrm{H}_{4}\right]$ tyrosine at steady-state (for exact details of the assumptions behind the method and calculations, see Thompson et al. 1989). In a modification of this method (for example, see Marchini et al. 1993) a second tyrosine tracer (L- $\left[{ }^{2} \mathrm{H}_{2}\right]$ tyrosine) is infused in order to measure total tyrosine $\mathrm{Ra}$ in arterial plasma, analogous to the measurement of total $\mathrm{CO}_{2}$ production in the leucine method.

The leucine tracer method requires three analytical instruments: a GC-mass spectrometer (MS) for measurement of the precursor pool enrichment: an isotoperatio MS (IRMS) for ${ }^{13} \mathrm{CO}_{2}$ enrichment; indirect calorimetry for total $\mathrm{CO}_{2}$ production. Furthermore, this method requires collection of both blood and breath, which is no problem in healthy subjects, but breath collections may be difficult in ill, weak, ventilated and anaesthetized patients. In clinical studies, therefore, the phenylalanine tracer method (Thompson et al. 1989) has often been chosen. It only requires blood collection and a GC-MS for the measurement of enrichment of the tracers in plasma.

General lessons learned from each of these tracers is that whole-body protein turnover in a $70 \mathrm{~kg}$ man is about $300 \mathrm{~g} / \mathrm{d}$. Also, each of the methods have shown that protein synthesis is increased after ingestion of mixed proteincontaining meals, while at the same time protein breakdown is reduced. Both effects appear to be mediated by increases in plasma insulin and increased plasma amino acid 
availability, although the reduction in breakdown can be achieved with increases in insulin only (Rooyackers \& Nair, 1997). As a consequence net protein deposition (protein synthesis $>$ protein breakdown) occurs in the fed state, while in the overnight fasted period the same amount of protein is broken down again (protein synthesis > protein breakdown) leading to net protein balance over $24 \mathrm{~h}$. Pacy et al. (1994) have reported that the amplitude of protein deposition (daytime) and net protein breakdown (night-time) increases with protein intake from about $35 \mathrm{~g}$ on a protein intake of $0.7 \mathrm{~g} / \mathrm{kg}$ body weight per $\mathrm{d}$ to values of about $90 \mathrm{~g}$ on a protein intake of $2 \cdot 5 \mathrm{~g} / \mathrm{kg}$ per $\mathrm{d}$.

Although all three tracers provide similar qualitative information in most studies, and even similar quantitative information in some studies, there are a number of clear exceptions. Particularly in studies where different tracers have been used simultaneously, some remarkable discrepancies have been observed, not only in quantification but also in the final physiological message. A few examples seen in our own group are mentioned here, many more can be found in the extensive literature (see Biolo et al. 1992; Wolfe et al. 1992; Marchini et al. 1993; Pacy et al. 1994).

Pannemans et al. (1997) measured the effect in elderly women of an increase in the protein content of the diet from 10 to $20 \%$ energy from protein in an attempt to understand the physiological basis behind the adequacy of the level of protein intake in elderly subjects with a low energy intake. Measurements were done during $12 \mathrm{~h}$ of overnight fasting for the $\left[{ }^{15} \mathrm{~N}\right]$ glycine method (according to the recommended protocol; Fern et al. 1981, 1985) and during the last $4 \mathrm{~h}$ of overnight fasting (07.00-11.00 hours, continuous infusion in laboratory) for the leucine tracer. The $\left[{ }^{15} \mathrm{~N}\right]$ glycine method indicated that the increase in protein intake significantly increased protein turnover (protein synthesis $+46 \%$, protein breakdown $+39 \%$ ), while the $\mathrm{L}-\left[1-{ }^{13} \mathrm{C}\right]$ leucine method indicated no change in protein turnover (protein synthesis $+2 \%$, protein breakdown $+5 \%$ ). Furthermore, the protein balance was more negative in the overnight fasting period with the glycine tracer than with the leucine tracer on both diets $(n 6)$ (10\% energy from protein: -58.4 (SD 11.7) v. -23.5 $(\mathrm{SD} 5 \cdot 3) \mathrm{g} / \mathrm{d}$ respectively; $20 \%$ energy from protein: -71.7 (SD 14.3) v. $-32.0(\mathrm{SD} 7.8) \mathrm{g} / \mathrm{d}$ respectively, $P<0.05$ in each case).

Recently we compared the effect of carbohydrate only ingestion ( $24 \mathrm{~g}$ taken every $30 \mathrm{~min}$ as a drink) with the effect of ingestion of a carbohydrate-protein mixture ( $24 \mathrm{~g}$ carbohydrate and $9 \mathrm{~g}$ rice-protein hydrolysate taken every $30 \mathrm{~min}$ as a drink) on protein turnover during the last $2 \mathrm{~h}$ of a $4 \mathrm{~h}$ period of infusion of both $\mathrm{L}-\left[1-{ }^{13} \mathrm{C}\right]$ leucine and $\mathrm{L}-\left[{ }^{2} \mathrm{H}_{5}\right]$ phenylalanine as tracers. The results are shown in Fig. 2. Both tracers indicate that ingestion of carbohydrate only does not lead to net protein deposition, which is expected, as human subjects otherwise could remain in $\mathrm{N}$ balance without protein ingestion. The findings with the leucine tracer seem to suggest that the additional anabolic effect of the carbohydrate-protein mixture is achieved primarily by a suppression of protein breakdown (-41\%), while findings with the phenylalanine tracer indicate that protein synthesis is stimulated $(+67 \%)$ and protein breakdown is reduced $(-39 \%)$. The net protein balance,

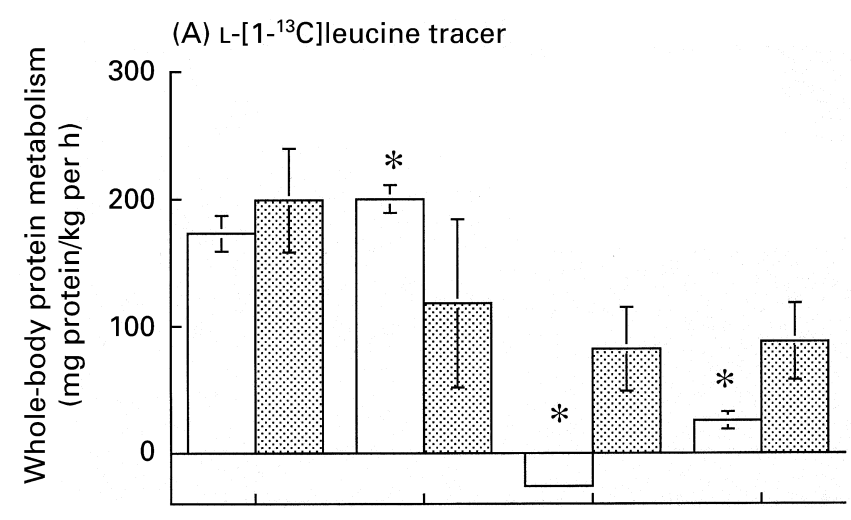

(B) $\mathrm{L}-\left[{ }^{2} \mathrm{H}_{5}\right]$ phenylalanine tracer

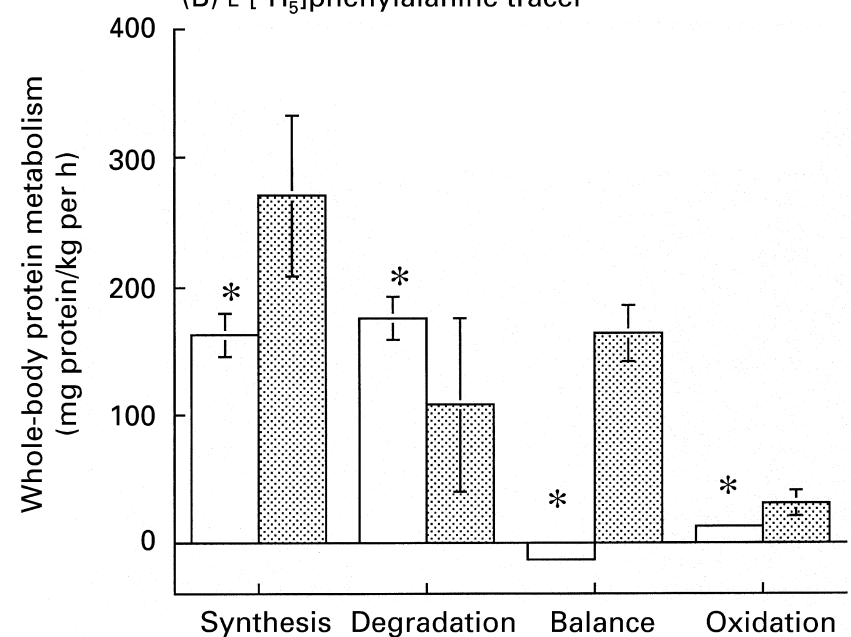

Fig. 2. Six subjects were investigated over $4 \mathrm{~h}$ while ingesting liquid solutions of either $24 \mathrm{~g}$ carbohydrate only $(\square)$ or $24 \mathrm{~g}$ carbohydrate plus $9 \mathrm{~g}$ rice-protein hydrolysate (-) every $30 \mathrm{~min}$. In the last $2 \mathrm{~h}$ a steady-state was achieved and blood samples were analysed for tracer enrichment, and the components of whole-body protein metabolism were calculated according to standard procedures. Mean value was significantly different from that for the carbohydrateprotein mixture: ${ }^{*} P<0 \cdot 05$. (From DLE Pannemans and AJM Wagenmakers, unpublished results.)

therefore, is 2-fold more positive with the latter tracer. Protein oxidation is $2-3$-fold higher with leucine as a tracer than with phenylalanine, with both ingestion of carbohydrate only and with carbohydrate-protein.

A discrepancy in outcome has also been observed (Wagenmakers et al. 1998) using these two tracers during exercise. With leucine as tracer, protein oxidation was 2- to 3 -fold higher during exercise of endurance-trained athletes ingesting carbohydrates than in the resting period and the recovery period, while protein synthesis was lower. Protein breakdown did not change during exercise. Net protein balance (synthesis-breakdown) was 2- to 3-fold more negative during exercise than during rest and during recovery. However, with phenylalanine as tracer, protein oxidation, synthesis and breakdown were similar at rest, during exercise and during recovery. Urea production (measured by plasma tracer dilution) also did not increase during exercise. These discrepancies raise concern in this case over the results given by the leucine tracer. 
These examples (and others in the literature, see Biolo et al. 1992; Wolfe et al. 1992; Marchini et al. 1993; Pacy et al. 1994) show that in the whole-body methodologies different tracers do not always provide similar information on the effect of physiological perturbations. This finding appears to indicate that one of the basic assumptions behind one or more of the methods is not always valid. An important assumption is that the size of the pool of the tracee (i.e. the free amino acid pool) does not change. It seems possible that this assumption does not hold for the free leucine pool during exercise. It has been shown convincingly that during exercise there is an increased uptake (Ahlborg et al. 1974; van Hall et al. 1996) and oxidation (Wagenmakers et al. 1989, 1991; van Hall et al. 1996) of branched-chain amino acids (leucine, isoleucine and valine) in muscle. Thus, the increased oxidation of the leucine tracer during exercise could reflect partial oxidation of intracellular leucine pools during the study and invalidate the steady-state assumption; i.e. the size of the free amino acid pool may not be constant (Fig. 1). This situation then leads to an overestimation of protein oxidation, an underestimation of protein synthesis (since turnover $=$ synthesis + oxidation) and a negative protein balance.

These suggestions do not necessarily imply that the message of the leucine tracer is less reliable than that of the phenylalanine tracer. Changes in the size of the phenylalanine pool cannot be ruled out. A relative increase in the size of the intracellular phenylalanine pool compared with that of the intracellular branched-chain amino acid pool could explain why the phenylalanine tracer gives lower protein oxidation rates than the leucine method in the studies described previously. It is also important to know that Marchini et al. (1993) have expressed a need for caution in interpreting data obtained with $\mathrm{L}-\left[{ }^{2} \mathrm{H}_{5}\right]$ phenylalanine as a tracer, because the oxidation rate observed was 2-fold lower in healthy subjects than oxidation rates measured with $\mathrm{L}-\left[1-{ }^{13} \mathrm{C}\right]$ phenylalanine as a tracer (calculated from the ${ }^{13} \mathrm{CO}_{2}$ production). This finding does not mean that $\left[{ }^{2} \mathrm{H}_{5}\right]$ phenylalanine should never be used, as there may be no other simple option if the aim, for instance, is to measure protein breakdown in patients during major surgery. However, it does imply that further research is needed on the metabolism and pool sizes of individual amino acids, and that different tracers of one amino acid and of different amino acids should be used before a definitive judgement can be made on the validity and accuracy of the whole-body methods.

The contribution of whole-body methodology (without parallel organ balances, biopsies, or protein separations) to the future gain of knowledge is expected to be limited due to the fact that most physiological disturbances have been investigated extensively (see Waterlow et al. 1978a; Waterlow, 1984; Rennie, 1985; Hasselgren, 1995; Wagenmakers \& Soeters, 1995; Rooyakers \& Nair, 1997; Wagenmakers, $1998 a, b$ ), and due to the lack of information on the relative contribution of various tissues and proteins to whole-body changes (e.g. an increase in protein synthesis in the liver may be compensated for by a decrease in protein synthesis in muscle).

\section{Amino acid incorporation methods to measure protein synthesis in tissues and specific proteins}

If the aim is to investigate the mechanism behind the loss of muscle mass and contractile function in a patient with sepsis, then we have to measure protein synthesis and protein breakdown in the muscle. One of the methods that can be used to measure the synthesis rate of total protein in tissue biopsies and of specific purified proteins is the amino acid-incorporation technique. The following key references can be consulted for details of the methodology to measure the synthesis rate of total mixed muscle protein (Rennie et al. 1982; Halliday et al. 1988; Nair et al. 1988; McNurlan et al. 1994), of muscle myofibrillar protein, myosin heavychain and cytoplasmic protein (Balagopal et al. 1997), of muscle mitochondrial protein (Rooyackers et al. 1996a,b), of total mixed liver and colonic mucosa protein (Stein et al. 1978; Heys et al. 1992; Barle et al. 1997), of plasma albumin (Gersovitz et al. 1980; Olufemi et al. 1990; Jahoor et al. 1994; Barle et al. 1997), of VLDL apolipoprotein B100 (Lichtenstein et al. 1990; Reeds et al. 1992; Halliday et al. 1993; Venkatesan et al. 1993, Jahoor et al. 1994) and of various other plasma proteins (Jahoor et al. 1996).

Many amino acid tracers $\left({ }^{15} \mathrm{~N}-,{ }^{13} \mathrm{C}\right.$ - or ${ }^{2} \mathrm{H}$-labelled $)$ have been used to enrich the amino acid precursor pool (Fig. 1). In most of these studies the tracer is given by a continuous intravenous infusion until a steady-state is obtained in the percursor pool for protein synthesis. To reach an early plateau the continuous infusion is often preceded by an intravenous priming dose of the tracer. Repeated samples are then taken at steady-state, the protein is precipitated from the biopsy sample and washed, or purified by various other techniques in the case of specific proteins. The protein is then hydrolysed and the amino acids, after derivatization, are analysed for tracer enrichment using GC-MS or GC-combustion-IRMS methodology. The rise in tracer enrichment in the protein-bound amino acid, over a given sampling time, is divided by the steady-state tracer enrichment in the precursor pool to give the fractional synthetic rate (FSR) of the protein, that is the percentage of the existing pool that has been synthesized over that time period. There has been a lot of discussion in the literature on which amino acid pool is the best reflection of the precursor pool for protein synthesis during continuous-infusion studies (Rooyackers \& Nair, 1997). It is undoubtedly the intracellular amino acyl-tRNA pool, but due to the technical difficulties of measuring enrichment in that pool various alternatives have been proposed. The plasma arterial and venous enrichment have both been used; the plasma venous $\alpha$-KIC enrichment is often used in the case of the $\mathrm{L}-\left[1-{ }^{13} \mathrm{C}\right]$ leucine tracer (assuming that $\mathrm{KIC}$, the transamination product of leucine, is formed in the amino acid compartment also used for protein synthesis), the intracellular amino acid enrichment can be determined in biopsies and a variety of indicators or products of the intracellular metabolism of the amino acid precursor pool have been used. It always seems best to measure the precursor amino acid in the intracellular free amino acid pool, but in cases where technical, methodological or ethical limitations prevent direct access, the venous plasma $\alpha$-KIC enrichment and some indirect indicators or products of the intracellular 
pool are acceptable alternatives (for details, see key references on methodology given earlier). Another method that has been used to administer the tracer is the so-called 'flooding dose' method. This method was introduced to eliminate problems with precursor pool enrichment, and relies on a bolus injection of large doses of a mixture of labelled and unlabelled amino acids (Garlick et al. 1989; McNurlan et al. 1994). Over the 60-120 min following the large bolus injection the tracer enrichment decreases sharply, but is nearly identical in the plasma and intracellular pools and is assumed to be identical to all aminoacyl-tRNA pools in all tissues. Protein-bound tracer amino acid is extracted from tissues (or other proteins) taken before and $90 \mathrm{~min}$ after the bolus injection. Protein FSR is calculated by dividing the increase in protein-bound tracer enrichment by the area under the curve of the venous plasma tracer enrichment. The method is fast and therefore theoretically suited for studies in unstable situations (e.g. critically-ill patients) and for investigating the early adaptation to physiological stimuli. However, concerns have been raised regarding the effect that the flooding dose of amino acids itself, or the concomitant metabolic changes (among others, increased plasma insulin levels since both leucine and phenylalanine are insulinotropic), may have on protein synthesis, as consistently higher FSR are measured in studies using the flooding-dose technique (Table 1). Flooding with leucine has been shown to increase the FSR of mixed muscle protein, measured using valine as the tracer, from 1.0 to $1.6 \% / \mathrm{d}$ (Smith et al. 1992) and the FSR of albumin from 6.0 to $10.3 \% / d$ (Smith et al. 1994). Readers interested in the theoretical background behind the continuing controversy on the optimal methodology to administer tracers and determine protein enrichment are referred to the detailed views of Garlick et al. (1994) and Rennie et al. (1994).

The most important lessons we have learned from the incorporation methods is that there are large (up to 425-fold) differences between the protein turnover rates in different tissues and in different proteins (Table 1). Subfractionation of muscle protein has shown that the myofibrillar proteins have the lowest turnover rates (about $1 \% / \mathrm{d}$ ) and that these rates decrease with age (Balagopal et al. 1997; Fig. 3). The highest FSR were seen in mitochondrial protein and again decreased with age (Rooyackers et al. 1996a), while the FSR of a cytosolic muscle protein fraction was intermediate and did not change with age (Fig. 3). The decrease in myofibrillar FSR may contribute to the gradual loss of actin and myosin in ageing muscles; while the decrease in mitochondrial protein FSR may lead to the known gradual loss of the muscle oxidative capacity, whole-body maximum $\mathrm{O}_{2}$ uptake and exercise capacity. The intravenous infusion of amino acids increased mixed muscle FSR in a group of healthy males (71 (SE 2) years) from $1 \cdot 1$ to $2 \cdot 3 \% / \mathrm{d}$ (Volpi et al. 1998), and therefore the authors suggested that muscle mass potentially could be better maintained with an increased intake of protein in elderly subjects. However, this suggestion was not confirmed by Welle \& Thornton (1998). During consumption of liquid meals (as repeated $30 \mathrm{~min}$ boluses) containing $7 \%$ energy as protein they observed a myofibrillar FSR of $1.6 \% / \mathrm{d}$ in a group of men and women aged $62-75$ years. An increase in the protein content of the meals to 14 and $28 \%$ energy did not further increase the myofibrillar FSR. However, resistance exercise increased the myofibrillar FSR on all diets by $20-37 \%$, but the observed increase did not differ between the diets. These findings seem to indicate that resistance exercise is the most powerful stimulus to counteract ageing-induced losses of myofibrillar protein, and that an increase in the protein content of the diet above normal has no effect under basal conditions and does not enhance the exercise-induced stimulus of muscle myofibrillar FSR. Together, these findings illustrate the fact that we need FSR measurements in specific muscle fractions and proteins to investigate important physiological questions about the mechanisms leading to muscle wasting and the loss of the oxidative capacity in the elderly. FSR

Table 1. Fractional protein synthesis (FSR) rates measured with a continuous infusion (continuous) and flooding dose (flood) in overnight fasted subjects; contributions of tissues to whole-body protein turnover (Qwb)

\begin{tabular}{|c|c|c|c|c|}
\hline \multirow[b]{2}{*}{ Organ or plasma protein } & \multicolumn{2}{|c|}{ FSR $(\% / d)$} & \multicolumn{2}{|c|}{$\%$ Qwb|| } \\
\hline & Continuous & Flood & Continuous & Flood \\
\hline Muscle* & $1 \cdot 15$ & 1.76 & 29 & 44 \\
\hline Livert & $12 \cdot 1$ & $24 \cdot 7$ & 11 & 22 \\
\hline Plasma albuminł & $5-6$ & $6-10$ & $2 \cdot 4$ & $3 \cdot 4$ \\
\hline VLDL apo-B100§ & 425 & - & 0.12 & - \\
\hline
\end{tabular}

* 'Continuous' FSR is based on mean values from Nair et al. (1988), Smith et al. (1992), Balagopal et al. (1997) and Volpi et al. (1998), and 'flood' FSR is based on mean values from Garlick et al. (1989) and McNurlan et al. $(1994,1996)$. Total muscle protein mass is estimated at $7 \mathrm{~kg}$ (muscle mass is $500 \mathrm{~g} / \mathrm{kg}$ body weight, muscle protein content is $200 \mathrm{~g} / \mathrm{kg}$ wet weight).

† 'Continuous' FSR is the mean of values from Stein et al. (1978) and Fearon et al. (1991), and 'flood' FSR value is from Barle et al. (1997). Liver protein mass is estimated at $250 \mathrm{~g}$. The higher FSR values in liver when measured using the 'flood' procedure, according to Barle et al. (1997), is a consequence of the fact that most of the export proteins have not yet escaped from the liver before the biopsy was taken ( 35 min after 'flood'), while a major part of the export proteins must have escaped in prolonged continuous-infusion studies. The underlying assumption must be that the mean synthesis rate of export proteins is much higher than that of the static liver proteins.

¥ 'Continuous' FSR is from Olufemi et al. (1990) and Smith et al. (1994), and 'flood' FSR is from Barle et al. (1997) and Smith et al. (1994). Plasma albumin (the major export protein; circulating pool $120-140 \mathrm{~g}$ ) has a lower FSR, while some other proteins (e.g. VLDL apolipoprotein B-100) have a very high FSR but a very small pool $(0.08 \mathrm{~g})$. There are many other liver export proteins, but only a few have values higher than the mixed liver FSR reported by Barle et al. (1997) (for values in young pigs, see Jahoor et al. 1996). The other potential reason for the differences between the two methods is that the 'flood' procedure itself, or the concomitant metabolic changes, increase protein synthesis per se (Smith et al. 1992, 1994; Rennie et al. 1994).

$\S$ VLDL apolipoprotein B100 data are from Venkatesan et al. (1993) using a continuous leucine infusion.

|| Qwb is assumed to be $280 \mathrm{~g} / 24 \mathrm{~h}$, a value based on an estimated mean value from the general literature obtained with the L-[1-13C]leucine method in overnight fasted lean $70 \mathrm{~kg}$ males. 


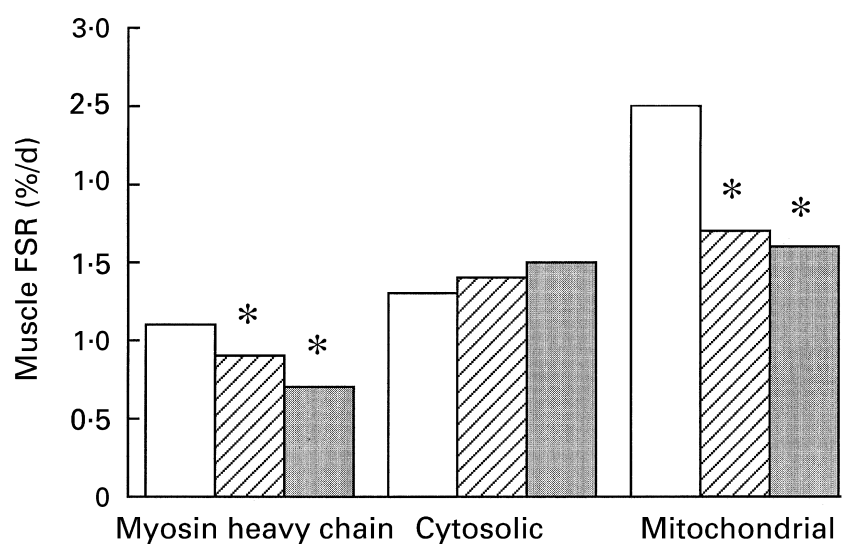

Fig. 3. Fractional protein synthesis rates (FSR) measured in three different age-groups in specific muscle proteins and protein fractions. $\square$, Mean age 24 years; m, mean age 53 years; $\boldsymbol{m}$, mean age 73 years. Mean values were significantly different from those for the youngest age-group (mean 24 years): ${ }^{*} P<0.05$. Summary of data published by Rooyackers et al. (1996a) and Balagopal et al. (1997).

measurements are also needed to investigate the effectiveness of nutritional and exercise interventions as a means of counteracting the loss of muscle mass, function and oxidative capacity during ageing and debilitating diseases. Skeletal muscle contributes $27-29 \%$ to wholebody protein turnover when measured using the continuousinfusion technique in the overnight fasted state (Table 1; Nair et al. 1988). The relative contribution of muscle to whole-body protein turnover seems to increase during ingestion of mixed meals and after strength training. When we divide the muscle FSR reported by Welle \& Thornton (1998) by a whole-body protein turnover of $334 \mathrm{~g} / \mathrm{d}$ during feeding (see values observed under similar conditions in the study depicted in Fig. 2) then muscle contributes $35 \%$ to whole-body protein turnover during ingestion of mixed meals, and even up to $45 \%$ during ingestion of mixed meals after strength training. It is quite clear that maintenance of these high protein deposition rates can lead to muscle hypertropy in subjects frequently involved in training sessions. Muscle in all cases is the tissue contributing most to wholebody turnover, despite the relatively low FSR (Table 1).

The amount of muscle protein produced is the balance between protein synthesis and breakdown. Theoretically, protein breakdown in tissues and individual proteins can be measured from the rate of loss of tracer enrichment in prelabelled proteins. However, reutilization of the tracer released by protein breakdown for protein synthesis leads to artificially-low rates, and the data critically depend on the time period over which the measurements are made (Waterlow et al. 1978a). Another difficulty, which has prevented the routine use of this technique in human subjects, is that several biopsies are required in periods of hours to many days, depending on the turnover rate, and that in some tissues, e.g. muscle, the enrichment at zero time is already close to the limits of reliable detection and then decreases with time. However, the development of new methodologies to measure low enrichments, and mathematical modelling (for example, see Zhang et al. 1996) should be able to solve most of these problems. Tracer enrichment is an important area of method development, since the protein content of tissues is the result of the balance between protein synthesis and breakdown.

Important practical advice to users of FSR methodology in mixed muscle protein is to clean the muscle fibres after freeze-drying, removing adherent blood and connective tissue under a dissection microscope, as otherwise substantial amounts of non-muscle protein may be present in the protein samples obtained after homogenization and acidification. Also, the determination of the precursor-pool enrichment and of the concentration of metabolites in the intramuscular water becomes less accurate and more variable when muscle fibres are not properly cleaned (Fig. 4 and Table 2). The enrichment of the tracer amino acid in proteins at the end of the infusion period depends on the turnover rate of the protein. In the case of proteins with a high turnover rate, only a few hours of tracer infusion are required to reach enrichment values of $>1$ molecule \% excess (tracer: tracee 0.01) and routine GC-MS tracer methodology can be used. Muscle proteins with a mean FSR of $1.15 \% / \mathrm{d}$ only have a $\mathrm{L}-\left[1-{ }^{13} \mathrm{C}\right]$ leucine enrichment of about 0.01 molecule $\%$ excess (trace : tracee $1 \times 10^{-4}$ ) after an infusion period of $6 \mathrm{~h}$. The traditional method of analysing such low enrichments is to isolate the proteinbound leucine by preparative GC (Read et al. 1984) followed by chemical decarboxylation of the C-1 (carrying the ${ }^{13} \mathrm{C}$ label) and measurement of ${ }^{13} \mathrm{CO}_{2}:{ }^{12} \mathrm{CO}_{2}$ by conventional dual-inlet IRMS following cryogenic purification of the $\mathrm{CO}_{2}$ (Read et al. 1984). More recently, preparative HPLC has been used to separate the leucine (Balagopal et al. 1996; Van Eijk et al. 1997), and the $\mathrm{CO}_{2}$ generated by ninhydrin decarboxylation was injected directly into a GC connected on line to a continuous-flow IRMS (Balagopal et al. 1996). However, this method still contains a number of laborious preparative steps. The reference method using modern GC-combustion-IRMS equipment, is therefore to measure such low enrichments directly in the hydrolysate after derivatization (Yarasheski et al. 1992; Balagopal et al. 1996). A disadvantage of the GC-combustion-IRMS method is the problem of dilution of ${ }^{13} \mathrm{C}$ label (C-1 of leucine) with natural $\mathrm{C}$ (of leucine and derivatization groups) generated during combustion. Thus, $\mathrm{N}$-acetylpropyl esters and N-heptafluoromethyl esters (in each, five $\mathrm{C}$ are added by derivatization) and $\mathrm{N}$-acetylmethyl esters (three $\mathrm{C}$ are added by derivatization) should preferentially be used for enrichment measurements of muscle protein. Even in the latter case, the L- $\left[1-{ }^{13} \mathrm{C}\right]$ leucine infusion should last at least $6 \mathrm{~h}$ to obtain an acceptable reproducibility in mixed muscle protein. Another way of solving this problem is the use of leucine with two or more $\mathrm{C}$ labelled with ${ }^{13} \mathrm{C}$, so that the dilution effect is reduced. For other proteins (e.g. plasma albumin; Van Acker et al. $1998 b)$, infusions of $3-4 \mathrm{~h}$ with $\mathrm{L}-\left[1-{ }^{13} \mathrm{C}\right]$ leucine generate more than enough enrichment and it also is possible to use tertiary-butyl-dimethylsilyl derivatives which add twelve unlabelled $\mathrm{C}$, but are much more stable than the other derivatives.

Despite immense improvements in sensitivity in recent years, modern GC-combustion-IRMS methodology still requires $50-500 \mu \mathrm{g}$ purified protein (more protein is needed with ${ }^{15} \mathrm{~N}$ tracers as most amino acids contain only one or two N). Such amounts can be obtained and purified only in 
experienced protein laboratories from relatively large biopsies (50-100 mg), but not in standard tracer laboratories. The easiest protein-purification technique in use to separate protein mixtures or subfractions into its individual pure components is PAGE (for examples of its use in tracer methodology, see Reeds et al. 1992; Sivakumar et al. 1994). However, the limitation is that only microgram amounts of pure proteins can be extracted from the protein bands on the gel. Again, this limitation is not a problem for highlyenriched proteins that can be analysed with a sensitive GC-MS method (for example, see Reeds et al. 1992; Jahoor et al. 1996). However, this limitation does present a problem for analysis of proteins with tracer enrichments below 0.5 molecule $\%$ excess (most proteins in fact). The tracer laboratories and suppliers of tracer MS, therefore, should focus on the development of improved equipment and methodology that either allows the measurement of lower enrichments with GC-MS equipment or improves the sensitivity of the existing GC-combustion-IRMS equipment. An elegant solution of the first type has been presented by Calder et al. (1992). In the case of tracers with multiple heavy atoms (e.g. L- $\left[{ }^{2} \mathrm{H}_{5}\right]$ phenylalanine) $M+5: M+3$ and $M+5: M+2$ (i.e. tracer:tracee) can be measured with greater precision and reproducibility in the low enrichment ranges than the $M+5: M$ (the traditional ratio used to estimate tracer : tracee in a compound with five heavy atoms). This method and its modifications have been successfully applied to the estimation of FSR in mixed muscle protein (McNurlan et al. 1994; Patterson et al. 1997). In our laboratory we are presently investigating whether the use of a large volume injector can reduce the protein requirement of the GC-combustion-IRMS by 50 - to 100 -fold. Currently it is still common practice in tracer laboratories to derivatize the protein hydrolysate in a volume of 50-100 $\mu \mathrm{l}$ and use only $1 \mu \mathrm{l}$ for injection into the GC-combustion-IRMS. Developments that reduce the amount of protein required are of immense importance, as they will allow the measurement of synthesis rates of a whole series of interesting proteins in studies investigating molecular adaptation mechanisms in various tissues in response to a variety of stimuli.

\section{Arterio-venous balance methods}

The net balance approach across tissues has been developed for the simultaneous measurement of protein synthesis and protein degradation rates, and has made important contributions to studies of muscle protein metabolism (Cheng et al. 1985, 1987; Barrett et al. 1987; Gelfand \& Barrett, 1987; Fryburg et al. 1995). In most of these studies it is assumed that the arterio-venous difference across the forearm or the leg primarily reflects muscle metabolism, and that tissues like skin, bone and subcutaneous fat contribute little (for reflections of validity of these assumptions, see Macdonald, 1999; van Hall et al. 1999a). Deep venous cannulation may reduce the contribution of non-muscle compartments to the arterio-venous exchange (Macdonald, 1999; van Hall et al. 1999a).

A tracer amino acid is given by primed continuous infusion, and in steady-state conditions a set of replicates (at least four) is obtained from both arterial and venous blood.
The net balance of the tracee amino acid (NB) is calculated from the formula:

$$
\mathrm{NB}=(\mathrm{Ca}-\mathrm{Cv}) \times \mathrm{F},
$$

where $\mathrm{Ca}$ and $\mathrm{Cv}$ are the concentration in arterial and venous blood respectively and $\mathrm{F}$ is the blood flow. In some of the published studies plasma concentrations and flow are used as no substantial amino acid transport takes place via the blood cells (plasma flow is derived from the blood flow using packed cell volume). The use of plasma implies that the estimated NB reflects a minimal flux rate. There is no consensus in the literature as to whether plasma or wholeblood measurements are preferable. In the absence of specific information on the participation of erythrocytes in the exchange of amino acids across a tissue it seems safe to choose whole-blood measurements. However, for many amino acids variations in concentration and enrichment are smaller when plasma is used. The net balance of the tracer (nb) is calculated from the formula:

$$
\mathrm{nb}=((\mathrm{Ca} \times \mathrm{Ea})-(\mathrm{Cv} \times \mathrm{Ev})) \times \mathrm{F},
$$

where Ea and Ev are the enrichment of the tracer in arterial and venous blood or plasma, $\mathrm{Ca}$ and $\mathrm{Cv}$ are the concentration in the arterial and venous blood respectively and $\mathrm{F}$ is the blood flow. The most simple and direct approach to assess protein synthesis and protein breakdown simultaneously is to measure NB and nb of an amino acid that is not transaminated or oxidized in muscle. In that case Rd into the tissue equals protein synthesis and is calculated from the formula:

$$
\text { protein synthesis }=\mathrm{Rd}=\mathrm{nb} / \mathrm{Ev} \text {. }
$$

$\mathrm{Ra}$ equals protein breakdown and is calculated from the formula:

$$
\text { protein breakdown }=\mathrm{Ra}=\mathrm{Rd}-\mathrm{NB} \text {. }
$$

Amino acids that are not (or only minimally) metabolized in muscle are methionine, tyrosine, phenylalanine, threonine, lysine and glycine (van Hall et al. 1999b). Protein synthesis and breakdown rates are obtained as $\mu$ mol chosen tracer/h over the cannulated tissue and can be converted to $g$ protein/h using the relative occurrence of the amino acid in muscle protein (g/100 g; Clowes et al. 1980). In most studies phenylalanine (relative occurrence in muscle protein $3.3 \mathrm{~g} / 100 \mathrm{~g}$ ) is used to calculate NB. In situations where there is a minimal imbalance between protein synthesis and protein breakdown or where the blood flow is large (e.g muscle during exercise, cardiac exchange at rest and during exercise), the arterio-venous concentration difference becomes small and NB variable. In these cases the more abundant amino acids (lysine $8.1 \mathrm{~g} / 100 \mathrm{~g}$ and threonine $5.4 \mathrm{~g} / 100 \mathrm{~g}$ ), and in particular the sum of the nonmetabolized amino acids, may give a more accurate estimate of NB (van Hall et al. 1999b).

Leucine tracers have also been used $\left({ }^{13} \mathrm{C},{ }^{14} \mathrm{C},{ }^{15} \mathrm{~N}\right.$ and doubly-labelled leucine) in arterio-venous difference studies. As $\mathrm{Rd}$ equals protein synthesis plus leucine 
oxidation plus release of leucine as its transamination product $(\alpha-\mathrm{KIC})$, it is also necessary to quantify NB and nb for $\mathrm{CO}_{2}$ and $\alpha$-KIC across forearm or leg. Quantification of leg ${ }^{13} \mathrm{CO}_{2}$ production requires correction factors that depend on the ${ }^{13} \mathrm{C}$ tracer position (van Hall, 1999). The disadvantage of the leucine tracer is that more measurements have to be made, each with their own variability, and that as a consequence the calculated synthesis rates become less accurate. The leucine method requires two analytical instruments, a GC-MS and an IRMS, while phenylalanine or lysine enrichments can be measured using one instrument (GC-MS). The advantage of leucine tracers is that information is also obtained on leucine oxidation and transamination (Cheng et al. 1985, 1987; Barrett et al. 1987).

Net fluxes of ${ }^{13} \mathrm{C}-,{ }^{15} \mathrm{~N}$ - and ${ }^{2} \mathrm{H}$-labelled amino acids across tissues, of course, are not only useful to investigate changes in protein turnover, but have also revealed the interorgan exchange of amino acids and the metabolic fates of amino acids in various tissues. For reviews of this important aspect of the physiology of amino acids, reference should be made to earlier reviews (for example, see Rennie, 1985, 1996; Wagenmakers \& Soeters, 1995; Wagenmakers, $1998 a, b)$.

\section{Three-compartment model}

The calculations used in the arterio-venous difference methods do not take into account the reutilization of amino acids derived from protein breakdown for protein synthesis, and therefore protein synthesis and protein breakdown are both underestimations. In order to overcome this limitation, Biolo et al. $(1995 a, b)$ extended the traditional arteriovenous model to a three-pool model by including the intramuscular pool of free amino acids. The additional information provided by the estimate of the enrichment of the tracer amino acid in the intramuscular water compartment theoretically allows calculations of synthesis and breakdown that include intracellular recycling. Further, the model includes calculations of the rate of transmembrane transport (from artery to muscle and from muscle to vein) and of the direct amino acid flow from artery to vein without entering the intramuscular compartment. The authors finally claim that the combined use of tracers of amino acids that are not metabolized in muscle (phenylalanine and lysine) and tracers that are metabolized (alanine and glutamine) allows calculation of the rate of de novo synthesis of alanine and glutamine in muscle (however, steady-state is a prerequisite).

A potential limitation of the three-compartment model, that apparently has not been realized by its proposers, is the inevitable limited precision and reproducibility of the estimates of the concentration of the tracer in the intramuscular water (for required calculations, see Fig. 4). In most studies done so far this estimate is a single estimate in one biopsy, while the estimates of concentration and enrichment in arterial and venous blood and of blood flow are traditionally made in sets of four to obtain an acceptable accuracy (see Macdonald, 1999). As pointed out in Fig. 4 muscle biopsies obtained by percutaneous needle contain blood and connective tissue between the fibres that is not

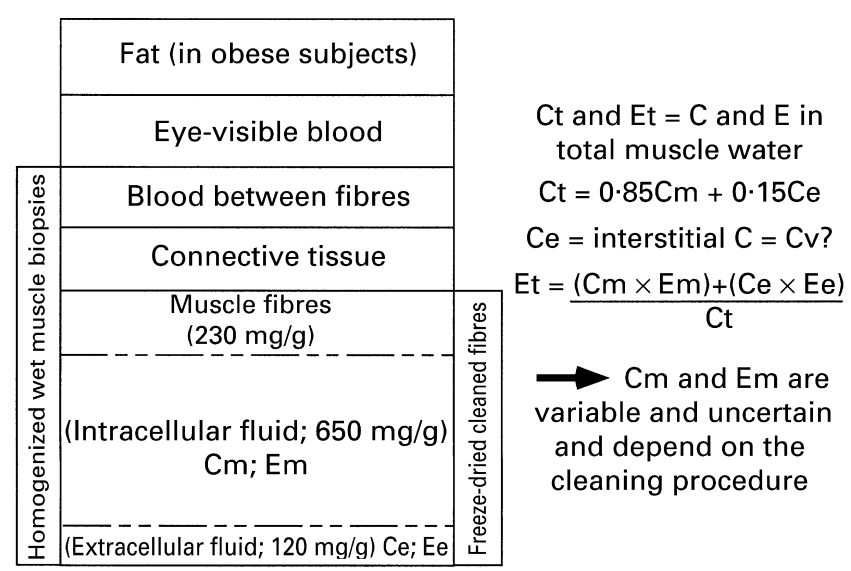

Fig. 4. Muscle and non-muscle constituents of a biopsy sample obtained by percutaneous needle: the potential impact of the cleaning procedure on the calculation of the concentration $(\mathrm{Cm})$ and enrichment $(\mathrm{Em})$ of an amino acid tracer in the intramuscular water compartment. $\mathrm{Ce}$ and $\mathrm{Ee}$ are the concentration and enrichment of the tracer respectively in the extracellular water compartment (interstitial fluid). In the three-pool model (Biolo et al. 1995a,b) Ce and Ee are assumed to have the same value as the concentration and enrichment of the tracer respectively in venous blood draining the leg or forearm ( $\mathrm{Cv}$ and Ev respectively). Ct and Et are concentration and enrichment of the tracer respectively measured in the total water pool of the biopsy. When biopsies are cleaned from eyevisible fat and blood only and freeze-dried, then typically $10-20 \%$ of the remaining dry mass is of non-muscle origin (blood and connective tissue between fibres). For a proper estimate of $\mathrm{Cm}$ and $\mathrm{Em}$ (essential variables in the calculations used in the three-pool model) muscle fibres in freeze-dried biopsies should be separated from nonmuscle constituents under a dissection microscope. Fractional synthesis rates in mixed muscle, for the same reason, should preferably also be done in purified muscle fibres or in purified protein subfractions, as otherwise blood proteins and collagen from connective tissue will be present. Metabolites present in muscle in much higher concentrations than those in blood or in non-muscle contaminants (creatine, phosphocreatine, adenine nucleotides, glycogen, glutamine, alanine, taurine etc.) for the same reason should be measured in purified muscle fibres (Table 2).

visible to the eye and therefore cannot be removed from wet muscle biopsies. Thus, in most muscle physiology laboratories it is routine procedure to freeze-dry the biopsies and free them of adherent blood and connective tissue. This cleaning procedure can easily be done under a dissection microscope, preferably in a dry atmosphere. Cleaned wet muscle biopsies after freeze-drying typically contain between 10 and $20 \%$ of non-muscle constituents; in extreme cases only $50 \%$ of the dry material actually consists of muscle fibres. The variation between subjects in the concentrations of muscle ATP and phosphocreatine, and of amino acids with a large gradient between muscle and blood (glutamate, alanine and glutamine) is reduced 5-fold or more when this procedure is applied (Table 2). Furthermore, cleaning of the muscle fibres leads to $20 \%$ higher mean concentrations of metabolites which are only present in the intramuscular water compartment (ATP and phosphocreatine) or which have a much higher concentration in the intramuscular water than in extracellular fluid (glutamine). In the case of glutamate, which has a high concentration in erythrocytes, cleaning did not influence the mean 
Table 2. Resting muscle concentration ( $\mu \mathrm{mol} / \mathrm{g}$ dry weight) of metabolites in homogenized freeze-dried biopsies; effect of removal of adherent blood and collagen under a dissection microscope*

(Mean values with their standard errors for eight subjects for procedure $\mathrm{A}$ and for six subjects for procedure B)

\begin{tabular}{|c|c|c|c|c|c|c|c|}
\hline \multirow[b]{2}{*}{ Metabolite } & \multicolumn{3}{|c|}{ without cleaning $(A)$} & \multicolumn{3}{|c|}{ with cleaning (B) } & \multirow[b]{2}{*}{$A / B(\%)$} \\
\hline & Mean & SEM & SEM/mean (\%) & Mean & SEM & SEM/mean (\%) & \\
\hline ATP & 21.5 & $5 \cdot 8$ & 27 & $27 \cdot 1$ & 0.8 & 3.0 & 79 \\
\hline $\mathrm{CrP}$ & 73.4 & $20 \cdot 7$ & 28 & 87 & $5 \cdot 0$ & $5 \cdot 7$ & 84 \\
\hline Glutamate & $12 \cdot 4$ & $5 \cdot 4$ & 44 & $12 \cdot 5$ & $1 \cdot 1$ & $8 \cdot 8$ & 99 \\
\hline Glutamine & $32 \cdot 3$ & $14 \cdot 0$ & 43 & $42 \cdot 0$ & 2.5 & $6 \cdot 0$ & 77 \\
\hline
\end{tabular}

CrP, creatine phosphate.

* Measurements were made in the same laboratory using the same analytical methodology and equipment (HPLC). The difference was that in procedure A the muscle was cleaned of eye-visible contaminations and then freeze-dried, weighed and homogenized, while in procedure B the biopsy was freeze-dried first, followed by removal of adherent blood and connective tissue from the muscle fibres and then weighing of cleaned muscle fibres and homogenization. Data for procedure $A$ are from Wagenmakers et al. (1991) (amino acid data from AJM Wagenmakers, EJ Beckers, F Brouns, H Kuipers, PB Soeters, GJ Van der Vusse and WHM Saris, unpublished results) and data of procedure B are from van Hall et al. (1995).

concentration (Table 2). The advice, therefore, is to always use the freeze-drying procedure and clean the biopsies from adherent blood and connective tissue (Table 2 and Fig. 4; Van Acker et al. 1998a) in studies which are estimating the concentration and enrichment of the tracer in the intramuscular water.

An important assumption in all balance studies is that the concentration and enrichment are constant in all the pools (blood and intracellular) during the study. There is some controversy in the literature about the presence of an intramuscular steady-state in the case of glutamine, alanine and glutamate, which all have large intracellular pools and a large gradient between muscle and blood. Biolo et al. (1995a) measured the mean intramuscular glutamine enrichment of four human subjects in the period between 5 and $11 \mathrm{~h}$ after the start of a primed continuous infusion of $\mathrm{L}-\left[5-{ }^{15} \mathrm{~N}\right]$ glutamine. The tracer: tracee value observed in the muscle pool $5 \mathrm{~h}$ after the start of the tracer infusion was 0.02 , and it did not change significantly until $11 \mathrm{~h}$ after the start of the infusion. However, the total amount of tracer administered in the first $5 \mathrm{~h}$ period was $11.76 \mathrm{mmol}$ when calculated for a subject weighing $70 \mathrm{~kg}$. Assuming that a $70 \mathrm{~kg}$ subject has a muscle glutamine pool of about $380 \mathrm{mmol}$ (Darmaun et al. 1986), then it can be calculated that the maximum enrichment in muscle could have been $11 \cdot 76 / 380=0.03$ if all the tracer given had been only directed into the muscle free amino acid pool. This calculation shows that $67 \%$ of the tracer administered must have entered the muscle and must have been trapped in the free glutamine pool in muscle, protected from further metabolism. This value seems unrealistically high given that the glutamine kinetic data of Biolo et al. (1995a) indicate that only $19 \%$ of the arterially-supplied glutamine is taken up by the muscle. Furthermore, glutamine tracer also enters the intracellular pools of all other organs and is used for protein synthesis in all organs of the body. Liver and the splanchnic bed extract glutamine very efficiently, as they have high glutaminase (EC 3.5.1.2) activities and a high oxidative capacity for glutamine (Marliss et al. 1971; Matthews et al. 1993). Thus, the enrichment measured by Biolo et al. (1995a), particularly that in the $5 \mathrm{~h}$ biopsy samples, seems a gross overestimation. Incomplete removal of blood, which has a much higher glutamine enrichment than muscle, would lead to such an overestimation. In contrast to Biolo et al. (1995a), Van Acker et al. (1998a) in our laboratory, using the recommended methodology to clean biopsies, observed a gradual linear increase in the muscle glutamine enrichment in twenty-one patients during infusions over 6-11 h. A similar gradual rise has also been observed in healthy subjects, continuing for more than $20 \mathrm{~h}$ (BAC Van Acker, AJM Wagenmakers, PB Soeters and MF Von Meyenfeldt, unpublished results). As the large intramuscular pools of glutamine do not reach steady-state within $20 \mathrm{~h}$ of tracer infusion, calculations of glutamine kinetics at the whole-body level and across tissues which assume a steady-state at earlier time-points are of limited value. The same conclusion may hold for other nonessential amino acids with a large intramuscular pool (alanine and glutamate).

We conclude, therefore, that the three-compartment model theoretically has advantages and could contribute important additional information to the arterio-venous difference methods, but muscle biopsies should be cleaned carefully after freeze-drying in order to obtain the best estimate of the enrichment of tracer in the intramuscular water. The same conclusion must hold for a procedure recently described to measure fractional breakdown rates of muscle protein from decreases in the enrichment of the tracer in the intramuscular water after stopping the tracer infusion (Zhang et al. 1996). Furthermore, additional validation is needed to show that the reproducibility of estimates of the enrichment of the tracer in the intramuscular water is good enough to lead to an acceptable variation in protein synthesis and breakdown rates and other calculated variables when the improved cleaning procedure is applied. Finally, calculations of kinetic variables of non-essential amino acids (glutamine, alanine and glutamate) should be made after steady-state has been reached in the intramuscular pool, which may take periods of $20 \mathrm{~h}$ and more.

\section{Important parallel measurements and future developments}

In the future most studies should focus on the measurement of the FSR of specific proteins in order to understand the mechanisms behind tissue adaptation in response to various stimuli (feeding, fasting, exercise, trauma, sepsis, disuse and disease). The step that most often precedes increased protein 


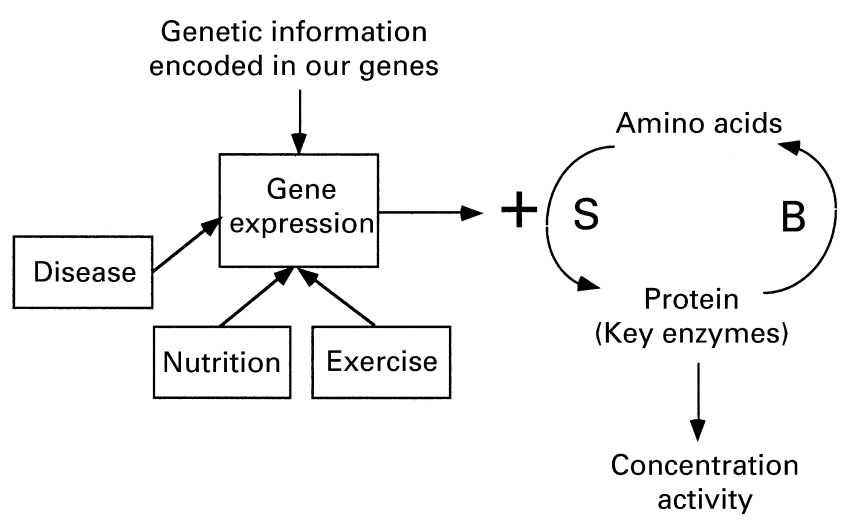

Fig. 5. Metabolic processes that control the protein and enzyme characteristics of a cell and that should be investigated in parallel in order to understand the metabolic adaptation of human metabolism to disuse, ageing, disease and major lifestyle changes (nutrition and physical activity). S, synthesis; B, breakdown.

synthesis rates is increased expression of genes (Fig. 5). Molecular biology techniques should be used in parallel in order to relate changes in mRNA levels to changes in the FSR of the same specific protein.

Whether the content of a protein or activity of an enzyme increases or decreases during adaptation is decided not only by the rate of protein synthesis but also by protein breakdown (Fig. 5). Reliable techniques should therefore be developed to measure the fractional breakdown rate of individual proteins. Skeletal muscle (like other tissues) contains three major proteolytic systems that are responsible for the breakdown of specific proteins. These systems are the lysosomal system, $\mathrm{Ca}^{2+}$-activated proteinases and the more recently (Fagan et al. 1987) discovered ubiquitinproteasome system (for review, see Attaix \& Taillandier, 1998). It has recently been discovered that the ubiquitinproteasome system is primarily responsible for the breakdown of the myofibrillar proteins. When actin and myosin dissociate from the myofibrils they are tagged by ubiquitin. The ubiquitinated proteins then form a recognizable substrate for the proteasome proteolytic system and are broken down to amino acids. It has recently been shown that the ubiquitin-proteasome system is up-regulated during starvation, denervation, disuse, cancer cachexia and sepsis, and thus contributes to protein wasting in these conditions. Thus, measurements of the proteasome activity, of the extent of ubiquitin tagging of specific proteins, and of mRNA levels of ubiquitin, of ubiquitincoupling proteins and of the proteasome subunits should be made in parallel with estimates of protein synthesis and degradation in studies investigating the mechanisms of muscle protein wasting during ageing and disease.

Finally, we have to reintroduce and further develop an area where we have lost rather than gained expertise in the last couple of years, i.e. enzymology. We also should continue our efforts to develop new methods to quantify protein concentrations in cells (immune labelling etc.). The end result of adaptation to the prolonged presence or absence of stimuli is a change in the activity and/or concentration of key enzymes in cellular metabolism. This change leads to changes in substrate fluxes in vivo which can be quantified with tracers. To quantify the end result and understand the link between cellular adaptation and general health we need parallel measurements of the activity of key enzymes, metabolic regulators and substrate fluxes in vivo.

\section{Acknowledgements}

The author thanks Professor David Halliday and Dr Olav Rooyackers for critical reading of the manuscript. The author also thanks his colleagues of NUTRIM (Nutrition and Toxicology Research Institute Maastricht) for their support to the tracer laboratory and for the joint research projects and helpful discussions that have contributed to the insights presented in this manuscript.

\section{References}

Ahlborg G, Felig P, Hagenfeldt L, Hendler R \& Wahren J (1974) Substrate turnover during prolonged exercise in man Splanchnic and leg metabolism of glucose, free fatty acids, and amino acids. Journal of Clinical Investigation 53, 1080-1090.

Attaix D \& Taillandier D (1998) The critical role of the ubiquitinproteasome pathway in muscle wasting in comparison to lysosomal and $\mathrm{Ca}^{2+}$-dependent systems. Advances in Molecular and Cell Biology 27, 235-266.

Balagopal P, Ford GC, Ebenstein DB, Nadeau DA \& Nair KS (1996) Mass spectrometric methods for determination of $\left[{ }^{13} \mathrm{C}\right]$ leucine enrichment in human muscle protein. Analytical Biochemistry 239, 77-85.

Balagopal P, Rooyackers OE, Adey DB, Ades PA \& Nair KS (1997) Effects of aging on in vivo synthesis of skeletal muscle myosin heavy-chain and sarcoplasmic protein in humans. American Journal of Physiology 273, E790-E800.

Barle H, Nyberg B, Essén P, Andersson K, McNurlan MA, Wernerman J \& Garlick PJ (1997) The synthesis rates of total liver protein and plasma albumin determined simultaneously in vivo in humans. Hepatology 25, 154-158.

Barrett EJ, Revkin JH, Young LH, Zaret BL, Jacob R \& Gelfand RA (1987) An isotopic method for measurement of muscle protein synthesis and breakdown in vivo. Biochemical Journal 245, 223-228.

Biolo G, Fleming RYD, Maggi SP \& Wolfe RR (1995a) Transmembrane transport and intracellular kinetics of amino acids in human skeletal muscle. American Journal of Physiology 268, E75-E84.

Biolo G, Maggi SP, Williams BD, Tipton KD \& Wolfe RR (1995b) Increased rates of muscle protein turnover and amino acid transport after resistance exercise in humans. American Journal of Physiology 268, E514-E520.

Calder AG, Anderson SE, Grant I, McNurlan MA \& Garlick PJ (1992) The determination of low d5phenylalanine enrichment (0.002-0.09 atom percent excess), after conversion to phenylethylamine, in relation to protein turnover studies by gas chromatography/electron ionization mass spectrometry. Rapid Communications in Mass Spectrometry 6, 421-424.

Cheng KN, Dworzak F, Ford GC, Rennie MJ \& Halliday D (1985) Direct determination of leucine metabolism and protein breakdown in humans using $\mathrm{L}-\left[1-{ }^{13} \mathrm{C},{ }^{15} \mathrm{~N}\right]$ leucine and the forearm model. European Journal of Clinical Investigation 15, 349-354.

Cheng KN, Pacy PJ, Dworzak F, Ford GC \& Halliday D (1987) Influence of fasting on leucine and muscle protein metabolism across the human forearm determined using $\mathrm{L}-\left[1-{ }^{13} \mathrm{C}\right.$, $\left.{ }^{15} \mathrm{~N}\right]$ leucine as the tracer. Clinical Science 73, 241-246. 
Clowes GHA, Randall HT \& Cha C-J (1980) Amino acid and energy metabolism in septic and traumatized patients. Journal of Parenteral and Enteral Nutrition 4, 195-205.

Darmaun D, Matthews D \& Bier D (1986) Glutamine and glutamate kinetics in humans. American Journal of Physiology 251, E117-E126.

Fagan JM, Waxman L \& Goldberg AL (1987) Skeletal muscle and liver contain a soluble ATP+ubiquitin-dependent proteolytic system. Biochemical Journal 243, 335-343.

Fearon KCH, McMillan DC, Preston T, Winstanley FP, Cruickshank AM \& Shenkin A (1991) Elevated circulating interleukin- 6 is associated with an acute-phase response but reduced fixed hepatic protein synthesis in patients with cancer. Annals of Surgery 213, 26-31.

Fern EB, Garlick PJ, McNurlan MA \& Waterlow JC (1981) The excretion of isotope in urea and ammonia for estimating protein turnover in man with $[15 \mathrm{~N}]$ glycine. Clinical Science $\mathbf{6 1}$, 217-228.

Fern EB, Garlick PJ \& Waterlow JC (1985) Apparent compartmentation of body nitrogen in one human subject: its consequences in measuring the rate of whole-body protein synthesis with ${ }^{15} \mathrm{~N}$. Clinical Science 68, 271-282.

Fryburg DA, Jahn LA, Hill SA, Oliveras DM \& Barrett EJ (1995) Insulin and insulin-like growth factor- 1 enhance human skeletal muscle protein anabolism during hyperaminoacidemia by different mechanisms. Journal of Clinical Investigation 96, 1722-1729.

Garlick PJ \& Fern EB (1985) Whole body protein turnover: theoretical considerations. In Substrate and Energy Metabolism, pp. 7-15 [JS Garrow and D Halliday, editors]. London: John Libbey.

Garlick PJ, McNurlan MA, Essén P \& Wernerman J (1994) Measurement of tissue protein synthesis rates in vivo: a critical analysis of contrasting methods. American Journal of Physiology 266, E287-E297.

Garlick PJ, Wernerman J, McNurlan MA, Essén P, Lobley GE, Milne E, Calder AG \& Vinnars E (1989) Measurement of the rate of protein synthesis in muscle of postabsorptive young men by injection of a 'flooding dose' of $\left[1-{ }^{13} \mathrm{C}\right]$ leucine. Clinical Science 77, 329-336.

Gelfand RA \& Barrett EJ (1987) Effect of physiologic hyperinsulinemia on skeletal muscle protein synthesis and breakdown in man. Journal of Clinical Investigation 80, 1-6.

Gersovitz M, Munro HN, Udall J \& Young VR (1980) Albumin synthesis in young and elderly subjects using a new stable isotope methodology: response to level of protein intake. Metabolism 29, 1075-1086.

Halliday D, Pacy PJ, Cheng KN, Dworzak F, Gibson JNA \& Rennie MJ (1988) Rate of protein synthesis in skeletal muscle in normal man and in patients with muscular dystrophy: a reassessment. Clinical Science 74, 237-240.

Halliday D, Venkatesan S \& Pacy P (1993) Apolipoprotein metabolism: a stable isotope approach. American Journal of Clinical Nutrition 57, 726S-731S.

Hasselgren P-O (1995) Counter-regulatory hormones and the role of cytokines in the control of amino acid metabolism. In Amino Acid Metabolism and Therapy in Health and Nutritional Disease, pp. 139-156 [LA Cynober, editor]. New York: CRC Press Inc.

Heys SD, Park KGM, McNurlan MA, Keenan RA, Miller JDB, Eremin O \& Garlick PJ (1992) Protein synthesis rates in colon and liver: stimulation by gastrointestinal pathologies. Gut 33, 976-981.

Jahoor F, Burrin DG, Reeds PJ \& Frazer M (1994) Measurement of plasma protein synthesis rate in infant pig: an investigation of alternative tracer approaches. American Journal of Physiology 267, R221-R227.

Jahoor F, Sivakumar B, Del Rosario M, Burrin D, Wykes L \& Frazer M (1996) Chronic protein deficiency differentially affects the kinetics of plasma proteins in young pigs. Journal of Nutrition 126, 1489-1495.

Lichtenstein AH, Cohn JS, Hachey DL, Millar JS, Ordovas JM \& Schaefer EJ (1990) Comparison of deuterated leucine, valine and lysine in the measurement of human apolipoprotein A-I and B-100 kinetics. Journal of Lipid Research 31, 1693-1701.

Macdonald I (1999) Arterio-venous differences to study macronutrient metabolism: introduction and overview. Proceedings of the Nutrition Society 58, 000-000.

McNurlan MA, Essén P, Thorell A, Calder AG, Anderson SE, Ljungqvist O, Sandgren A, Grant I, Tjäder I, Ballmer PE, Wernerman J \& Garlick PJ (1994) Response of protein synthesis in human skeletal muscle to insulin: an investigation with L- $\left[{ }^{2} \mathrm{H}_{5}\right]$ phenylalanine. American Journal of Physiology 267, E102-E108.

McNurlan MA, Sandgren A, Hunter K, Essén P, Garlick PJ \& Wernerman J (1996) Protein synthesis rates of skeletal muscle, lymphocytes, and albumin with stress hormone infusion in healthy man. Metabolism 45, 1388-1394.

Marchini JS, Castillo L, Chapman TE, Vogt JA, Ajami A \& Young VR (1993) Phenylalanine conversion to tyrosine: comparative determination with $\mathrm{L}$-[ ring $\left._{-}{ }^{2} \mathrm{H}_{5}\right]$ phenylalanine and $\mathrm{L}-\left[1-{ }^{13} \mathrm{C}\right]$ phenylalanine as tracers in man. Metabolism 42, 1316-1322.

Marliss EB, Aoki TT, Pozefsky T, Most AS \& Cahill GF (1971) Muscle and splanchnic glutamine and glutamate metabolism in postabsorptive and starved man. Journal of Clinical Investigation 50, 814-817.

Matthews DE, Marano M \& Campbell RG (1993) Splanchnic bed utilization of glutamine and glutamic acid in humans. American Journal of Physiology 264, E848-E854.

Matthews DE, Motil KJ, Rohrbaugh DK, Burke JF, Young VR \& Bier DM (1980) Meausurement of leucine metabolism in man from a primed, continuous infusion of $\mathrm{L}-\left[1{ }^{13} \mathrm{C}\right]$ leucine. American Journal of Physiology 238, E473-E479.

Matthews DE, Schwarz HP, Yang RD, Motil KJ, Young VR \& Bier DM (1982) Relationship of plasma leucine and $\alpha$-ketoisocaproate during a $\mathrm{L}-\left[1-{ }^{13} \mathrm{C}\right]$ leucine infusion in man: a method for measuring human intracellular tracer enrichment. Metabolism 31, 1105-1112.

Nair KS, Halliday D \& Griggs RC (1988) Leucine incorporation into mixed skeletal muscle protein in humans. American Journal of Physiology 254, E208-E213.

Olufemi OS, Humes P, Whittaker PG, Read MA, Lind T \& Halliday D (1990) Albumin synthetic rate: a comparison of arginine and alpha-ketoisocaproate precursor methods using stable isotope techniques. European Journal of Clinical Nutrition 44, 351-361.

Pacy PJ, Price GM, Halliday D, Quevedo MR \& Millward DJ (1994) Nitrogen homeostasis in man: the diurnal responses of protein synthesis and breakdown and amino acid oxidation to diets with increasing protein intakes. Clinical Science 86, $103-118$.

Pannemans DLE, Wagenmakers AJM, Westerterp KR, Schaafsma G \& Halliday D (1997) The effect of an increase of protein intake on whole-body protein turnover in elderly women is tracer dependent. Journal of Nutrition 127, 1788-1794.

Patterson BW, Zhang XJ, Chen Y, Klein S, Wolfe RR (1997) Measurement of very low isotope enrichments by gas chromatography/mass spectrometry: application to measurement of muscle protein synthesis. Metabolism 46, 943-948. 
Read WW, Read MA, Rennie MJ, Griggs RC \& Halliday D (1984) Preparation of $\mathrm{CO}_{2}$ from blood and protein-bound amino acid carboxyl groups for quantification and ${ }^{13} \mathrm{C}$-isotope measurements. Biomedical Mass Spectrometry 11, 40-44.

Reeds PJ, Hachey DL, Patterson BW, Motil KJ \& Klein PD (1992) VLDL apolipoprotein B-100, a potential indicator of the isotopic labeling of the hepatic protein synthetic precursor pool in humans: Studies with multiple stable isotopically labeled amino acids. Journal of Nutrition 122, 457-466.

Rennie MJ (1985) Muscle protein turnover and the wasting to injury and disease. British Medical Bulletin 41, 257-264.

Rennie MJ (1996) Influence of exercise on protein and amino acid metabolism. In Handbook of Physiology. Section 12, Exercise: Regulation and Integration of Multiple Systems, pp. 995-1035 [LB Rowell and JT Shepherd, editors]. Oxford: Oxford University Press.

Rennie MJ, Edwards RHT, Halliday D, Matthews DE, Wolman SL \& Millward DJ (1982) Muscle protein synthesis measured by stable isotope techniques in man: the effects of feeding and fasting. Clinical Science 63, 519-523.

Rennie MJ, Smith K \& Watt PW (1994) Measurement of human tissue protein synthesis: an optimal approach. American Journal of Physiology 266, E298-E307.

Rooyackers OE, Adey DB, Ades PA \& Nair KS (1996a) Effect of age on in vivo rates of mitochondrial protein synthesis in human skeletal muscle. Proceedings of the National Academy of Sciences USA 93, 15364-15369.

Rooyackers OE, Kersten AH \& Wagenmakers AJM (1996b) Mitochondrial protein content and in vivo synthesis rates in skeletal muscle from critically ill rats. Clinical Science 91, 475-481.

Rooyakers OE \& Nair KS (1997) Hormonal regulation of human muscle protein metabolism. Annual Review of Nutrition 17, 457-485.

Sivakumar B, Jahoor F, Burrin DG, Reeds PJ \& Frazer M (1994) Fractional synthetic rates of retinol binding protein and transthyretin measured by stable isotope techniques in neonatal pigs. Journal of Biological Chemistry 269, 26196-26200.

Smith K, Barua JM, Watt PW, Scrimgeour CM \& Rennie MJ (1992) Flooding with $\mathrm{L}-\left[1-{ }^{13} \mathrm{C}\right]$ leucine stimulates human muscle protein incorporation of continuously infused $\mathrm{L}-\left[1-{ }^{13} \mathrm{C}\right]$ valine. American Journal of Physiology 262, E372-E376.

Smith K, Downie S, Barua JM, Watt PW, Scrimgeour CM \& Rennie MJ (1994) Effect of a flooding dose of leucine in stimulating incorporation of constantly infused valine into albumin. American Journal of Physiology 266, E640-E644.

Stein TP, Mullen JL, Oram-Smith JC, Rosato EF, Wallace HW \& Hargrove WC III (1978) Relative rates of tumor, normal gut, liver and fibrinogen protein synthesis in man. American Journal of Physiology 234, E648-E652.

Thompson GN, Pacy PJ, Merritt G, Ford GC, Read MA, Cheng KN \& Halliday D (1989) Rapid measurement of whole body and forearm protein turnover using a $\left[{ }^{2} \mathrm{H}_{5}\right]$ phenylalanine model. American Journal of Physiology 256, E631-E639.

Van Acker BAC, Hulsewé KWE, Wagenmakers AJM, Deutz NEP, Van Kreel BK, Halliday D, Matthews DE, Soeters PB \& Von Meyenfeldt MF (1998a) Absence of glutamine isotopic steady state: Implications for studies on glutamine metabolism. Clinical Science 95, 339-346.

Van Acker BAC, Hulsewé KWE, Wagenmakers AJM, Deutz NEP, Von Meyenfeldt MF \& Soeters PB (1998b) Effect of surgery on albumin synthesis rate in humans. Clinical Nutrition 17, 14-15.

Van Eijk HMH, Rooyakkers DR, Wagenmakers AJM, Soeters PB \& Deutz NEP (1997) Isolation and quantitation of isotopically labeled amino acids from biological samples. Journal of Chromatography 691B, 287-296.

van Hall G (1999) Correction factors for ${ }^{13} \mathrm{C}$-labelled substrate oxidation at whole-body and muscle level. Proceedings of the Nutrition Society 58, 979-986.

van Hall G, González-Alonso J, Sacchetti M \& Saltin B (1999a) Skeletal muscle substrate metabolism during exercise: methodological considerations. Proceedings of the Nutrition Society 58, 899-912.

van Hall G, MacLean DA, Saltin B \& Wagenmakers AJM (1996) Mechanisms of activation of muscle branched-chain $\alpha$-keto acid dehydrogenase during exercise in man. Journal of Physiology 494, 899-905.

van Hall G, Saltin B, van der Vusse GJ, Söderlund K \& Wagenmakers AJM (1995) Deamination of amino acids as a source for ammonia production in human skeletal muscle during prolonged exercise. Journal of Physiology 489, 251-261.

van Hall G, Saltin B \& Wagenmakers AJM (1999b) Muscle protein degradation during prolonged one leg cycle exercise in man. Clinical Science (In the Press).

Venkatesan S, Cullen P, Pacy P, Halliday D \& Scott J (1993) Stable isotopes show a direct relation between VLDL ApoB overproduction and serum triglyceride levels and indicate a metabolically and biochemically coherent basis for familial combined hyperlipidemia. Arteriosclerosis and Thrombosis 13, $1110-1118$.

Volpi E, Ferrando AA, Yeckel CW, Tipton KD \& Wolfe RR (1998) Exogenous amino acids stimulate net muscle protein synthesis in the elderly. Journal of Clinical Investigation 101, 2000-2007.

Wagenmakers AJM (1998a) Protein and amino acid metabolism in human muscle. Advances in Experimental Medicine and Biology 441, 307-319.

Wagenmakers AJM (1998b) Muscle amino acid metabolism at rest and during exercise: role in human physiology and metabolism. Exercise and Sports Science Reviews 26, 287-314.

Wagenmakers AJM \& Soeters PB (1995) Metabolism of branchedchain amino acids. In Amino Acid Metabolism and Therapy in Health and Nutritional Disease, pp. 67-83 [LA Cynober, editor]. New York: CRC Press Inc.

Wagenmakers AJM, Beckers EJ, Brouns F, Kuipers H, Soeters PB, Van der Vusse GJ \& Saris WHM (1991) Carbohydrate supplementation, glycogen depletion, and amino acid metabolism during exercise. American Journal of Physiology 260, E883-E890.

Wagenmakers AJM, Brookes JH, Coakley JH, Reilly T \& Edwards RHT (1989) Exercise-induced activation of the branched-chain 2-oxo acid dehydrogenase in human muscle. European Journal of Applied Physiology and Occupational Physiology 59, 159-167.

Wagenmakers AJM, Pannemans DLE, Jeukendrup AE, Gijsen AP, Senden JMG, Halliday D \& Saris WHM (1998) Protein metabolism during exercise and recovery. Proceedings of the Nutrition Society 57, 7A.

Waterlow JC (1984) Protein turnover with special reference to man. Quarterly Journal of Experimental Physiology 69, 409-438.

Waterlow JC, Garlick PJ \& Millward DJ (1978a) Protein Turnover in Mammalian Tissues and in the Whole Body. Amsterdam: Elsevier North Holland.

Waterlow JC, Golden MH \& Garlick PJ (1978b) Protein turnover in man measured with ${ }^{15} \mathrm{~N}$ : comparison of end products and dose regimes. American Journal of Physiology 235, E165-E174.

Watt PW, Corbett ME \& Rennie MJ (1992) Stimulation of protein synthesis in pig skeletal muscle by infusion of amino acids during constant insulin availability. American Journal of Physiology 263, 453-460. 
Welle S \& Thornton CA (1998) High protein meals do not enhance myofibrillar synthesis after resistance exercise in 62- to 75-yr-old men and women. American Journal of Physiology 274, E677-E683.

Yarasheski KE, Smith K, Rennie MJ \& Bier DM (1992) Measurement of muscle protein fractional synthetic rate by capillary gas chromatography/combustion isotope ratio mass spectrometry. Biological Mass Spectrometry 21, 486-490.

Zhang X-J, Chinkes DL, Sakurai Y \& Wolfe RR (1996) An isotopic method for measurement of muscle protein fractional breakdown rate in vivo. American Journal of Physiology 270, E759-E767. 